УДК $781.1+781.2$

DOI https://doi.org/10.32782/facs-2021-1-8

\title{
Вікторія КАШАЮК
}

кандидат мистецтвознавства, доцент, доцент кафедри історії та теорії мистецтв, Волинський національний університет імені Лесі Українки, просп. Волі, 13, м. Луцьк, Волинська обл., Україна, 43025,vdraganchuk.ukr@gmail.com

ORCID: 0000-0003-4396-8946

Бібліографічний опис статті: Кашаюк, В. (2021). Феномен ментальності в експлікаціях сучасного українського музикознавства. Fine Art and Culture Studies, 1, 50-58, doi: https://doi.org/10.32782/facs-2021-1-8

\section{ФЕНОМЕН МЕНТАЛЬНОСТІ В ЕКСПЛІКАЦЯХ СУЧАСНОГО УКРАЇНСЬКОГО МУЗИКОЗНАВСТВА}

Одним із понять, щчо протягом останніх десятиліть наповнюється музикознавчим змістом, є ментальність, крізь призму якої аналізуються тенденції та явища музичної культури. Відтак, актуальною музикознавчою проблемою є систематизаџія та узагальнення знань та ідей з метою формування цілісного уявлення про ментальні риси певних музичних культур та їхні прояви в академічному мистецтві.

Мета статmі - на основі наукових експлікацій ментальності створити ескізне бачення феномену у сучасному украӥнському музикознавстві.

Методологія дослідження відображена у таких його завданнях: 1) аналіз основних досліджень проблеми ментальності в украӥнському музикознавстві; 2) вирізнення головних ідей провідних вітчизняних вчених щзодо вказаного феномену; 3) привнесення власної думки в опраџювання задачі; 4) узагальнення та розкриття перспектив подальших досліджень даної теми.

Наукова новизна. У статті прослідковано розвиток української музикознавчої думки щцодо феномену ментальності та вирізнено головні здобутки вітчизняних вчених у иъьому ракурсі. Задекларовано ідею про диференціацію архетипів колективного безсвідомого, які є основою художньої творчості, на два типи: інваріантні («символи») та варіантні («символи символів»).

Висновок. Серед найбільш вагомих здобутків щзодо піднятої проблеми є ідеї І. Ляменка про диференціацією способів мислення як ментальних виявів, Н. Горюхіної та Н. Герасимовою-Персидської про національну ідентичність в музиці, Л. Кияновської про кордоцентризм і стилістичну акласичність в украӥнській музиці, О. Катрич про діонісійський архетип як домінуючий в украӥнському музично-виконавському стилетворенні, диференціація М. Севериновою рівнів художнього мислення у відповідності до положень теорії колективного безсвідомого К. Г. Юнта та ін.

Ключові слова: музична ментальність, українська музична ментальність, відображення архетипів в музиці, сучасне українське музикознавство.

\section{Viktoriia KASHAIUK}

PhD in Art Criticism, Associate Professor at the Department of Arts History and Theory, Lesya Ukrainka Volyn National University, 13 Voli ave., Lutsk, Volyn region, Ukraine, 43025,vdraganchuk.ukr@gmail.com ORCID: 0000-0003-4396-8946

To cite this article: Kashaiuk, V.(2021). Fenomen mentalnostiv eksplikatsiiakh suchasnoho ukrainskoho muzykoznavstva [Mentality phenomenon in the explications of modern Ukrainian musicology]. Fine Art and Culture Studies, 1, 50-58, doi: https://doi.org/10.32782/facs-2021-1-8

\section{MENTALITY PHENOMENON IN THE EXPLICATIONS OF MODERN UKRAINIAN MUSICOLOGY}

One of the concepts that has been filled with musicological content in recent decades is the mentality, through the prism of which trends and phenomena of musical culture are analyzed. Thus, the current musicological problem is the systematization and generalization of knowledge and ideas in order to form a holistic view about the mental features of certain musical cultures and their academic art manifestations.

The aim of the article - on the basis of mentality scientific explanations to create a sketch vision of this phenomenon in modern Ukrainian musicology. 
Research methodology is reflected in the following problems: 1) analysis of basic research on the problem of mentality in Ukrainian musicology; 2) highlighting the main ideas of leading domestic scientists on this phenomenon; 3) introduction of own opinion in processing of a task; 4) generalization and disclosure of prospects for further research on this topic.

Scientific novelty. The development of Ukrainian musicological thought on the mentality phenomenon and highlights the main achievements of domestic scientists in this perspective is followed in the article. The idea about differentiating the collective unconscious archetypes as artistic creativity basis into two types is declared: invariant («symbols») and variant («symbols of symbols»).

Conclusion. Among the most important achievements on the raised problem are the following ideas. I. Liashenko's idea about the differentiation of thinking ways as mental manifestations, ideas by N. Goryukhina and N. GerasimovaPersidskaya about national identity in music, by L. Kyianovska on cordocentrism and stylistic aclassicism in Ukrainian music, by O. Katrych about the Dionysian archetype as dominant in Ukrainian musical-performing stylistics, M. Severinova's differentiation of artistic thinking levels in accordance with the provisions of the K. H. Jung's collective unconscious theory and others.

Key words: musical mentality, Ukrainian musical mentality, archetypes reflections in music, modern Ukrainian musicology.

Актуальність проблеми. Ситуація у сучасному українському музикознавстві, яке все активніше розширює рамки історичного та теоретичного підходів до вивчення музичних явищ та прагне долучитися до загальноєвропейських тенденцій розвитку музикознавства систематичного, вимагає залучення до наукового пошуку вирішення актуальних проблем музичного мистецтва підходів, притаманних для філософії, соціології, психології, педагогіки та ін. Одним із понять, що протягом останніх десятиліть наповнюється музикознавчим змістом, $\epsilon$ ментальність, крізь призму якої аналізуються як загальні тенденції та явища музичної культури (відображення національних ментальності, характеру та ідентичності в музиці, архетипи української музичної культури, українська національна музична мова та ін.), так і окремі мистецькі композиційні (жанрові, стильові та ін.) та виконавські особливості. Відтак, постала вагома потреба проведення досліджень, в яких би здійснювалися систематизація та узагальнення таких знань та ідей, -3 метою формування певного цілісного уявлення про ментальні риси української та інших музичних культур та їхні прояви в академічному мистецтві.

Аналіз останніх досліджень і публікацій. Аналізуючи основні дослідження із задекларованої проблематики, насамперед, згадаємо працю С. Людкевича (1999) «Націоналізм у музиці», вперше опубліковану 1905-го року у часописі «Артистичний вісник». Оскільки згодом, під цензурою радянської доктрини, подібні наукові пошуки були заборонені, то вважаємо за потрібне нагадати ії прикінцеву думку. Охоплений ідею до романтичного національного піднесення української культури у контексті та за прикладом пасіонарного руху культур європей- ських (під впливом відомої «весни народів» 1848-го року та інших подій), мистець у справі розвитку модерних українських літератури та музики головну роль відвів національному способу мислення, та прийшов до висновку, що «оригінального, живого музичного стилю не створять нам ніякі родоводи іiї [музики] старинності чи грецького походження, ані непохітна віра в готові догми німецького контрапункту, ні готові рецепти на гармонізацію народних пісень, - а здорові, вільні, елементарні пориви і змагання життя і штуки» (Людкевич, 1999: 52). Власне, результати згаданих «поривів і змагань» i $\epsilon$, на нашу думку, тим сутнісним ядром, яке формує музичну ментальність певної культури, що відображається у композиторській та виконавській творчості як національний стиль і спосіб мислення, тобто ментальність.

Важливі ідеї, на які можемо сьогодні спиратися у контексті дослідження проблеми «ментальність і музика», висловлено у працях багатьох корифеїв українського музикознавства. Вагомі здобутки у даному напрямку здійснено у працях І. Ляшенка (1973; 1991), який, відштовхуючись від ідеї про історично-процесуальну роль національних традицій для розвитку та оновлення української музики, приходить до обгрунтування та диференціації національного та інтернаціонального в музиці, що, по суті, $\epsilon$ диференціацією національного та універсального способів мислення як ментальних виявів. Дослідження певних аспектів національної ментальності та ідентичності проводилося у працях Н. Горюхіної (1985), Н. ГерасимовоїПерсидської (1999) та ін.

Серед останніх досліджень, в яких підіймаються філософські психологічні, соціологічні аспекти впливу ментального фактору 
на музичне мистецтво, вирізнимо низку праць Л. Кияновської та представників школи вченої, в яких крізь цю призму аналізуються культурноісторичні процеси в українському мистецтві останніх століть і творчість його «знакових» діячів, а також ставляться питання про тенденції розвитку музикознавства на сучасному етапі (Кулик, 2019); праці О. Козаренка (2001) 3 проблем української національної музичної мови, М. Северинової (Архетипи..., 2013) про роль архетипів у композиторському мисленні, О. Самойленко (2004) про психологічні чинники у культурологічному аналізі, О. Безбородька (2010) про реальність впливу національно-специфічного звучання вербальної мови та національно-вербального фактору музичної діяльності на творення i сприйняття музики, X. Казимирів (2018) про історикокультурологічний аспект втілення міфологеми землі в українській професійній музиці, Г. Плечелюк (2016) про диференціацію форм архетипу Переродження та його інтерпретацію в музиці та ін.

Протягом останніх років проблему ментальності екстрапольовано на вивчення розмаїтих явищ музичного мистецтва - український хоровий спів (Бенч-Шокало, 2002), вокальне мистецтво (Антонюк, 2001), (Присталов, 2008), національну ідентичність (Корній, 2008), (Новакович, 2020), (Ярко, 2021), виконавське стилетворення (Катрич, 1996), функціонування різноманітних архетипів та міфологем, розвиток окремих жанрів і багато інших проблем композиторської та виконавської творчості.

Мета статті - відштовхуючись від результатів попередніх здобутків, на основі наукових експлікацій ментальності створити ескізне бачення феномену у сучасному українському музикознавстві. Завдання дослідження полягають у наступному: 1) проаналізувати основні дослідження проблеми ментальності в українському музикознавстві; 2) вирізнити головні ідеї провідних вітчизняних вчених щодо вказаного феномену; 3) привнести власну думку в опрацювання задачі; 4) здійснити узагальнення та розкрити перспективи подальших досліджень даної теми.

Виклад основного матеріалу. Аналіз музикознавчих експлікацій феномену ментальності розпочнемо із концепції української музичної ментальності Л. Кияновської (2001), яку можемо «прочитати» на основі ідей, вислов- лених у процесі компаративного огляду українського музичного романтизму та його європейського контексту. Специфіку ситуації, що склалася $з$ українською художньою школою, дослідниця пояснює формуванням у добу романтизму, фактично, двох шкіл - у східній і західній частинах України, яка була розділена між Російською та Австро-Угорською імперіями. Розвиток кожної із вказаних шкіл позначений низкою характерних історико-соціальних прикмет. При спільності музичної мови, фольклорних джерел і загальнозначимих образів і тем східна і західна школи, все ж, виявляють суттєву різницю у колі художніх інтересів, несинхронній реакції на провідні стильові віяння Свропи, використанні різних виразових систем. (Нагадаємо, цьому до протягом останніх століть, до кінця $1930-$ - років сприяли можливості західноукраїнських мистців навчатися у європейських культурних центрах та співпрацювати з їхніми провідними діячами i, водночас, не бути залежними у творчості від російського і радянського імперсько-тоталітарного тиску, який витримували мистці із Наддніпрянщини, і який від рубіжного 1939 року поширився на усі терени України). Разом із тим, авторка стверджує, що національна ментальність українців, як свідчить трьохсотлітній розвиток професійної музичної культури від Миколи Дилецького і класиків «золотої доби» до «знакового» модерніста Бориса Лятошинського та його учнів-«шістдесятників», $є$ досить стабільним поняттям, хоча й не відкривається 3 першого погляду. Головним чинником єдності дослідниця вважає духовну спільність, яка стоїть вище регіональної окремішності та, водночас, $є$ гарантом певних постійних засадничих ознак і спільного способу музичного мислення. Визначаючи найістотніші прикмети національної музичної ментальності, Л. Кияновська називає наступні: «сердечність, м'яка лірика, тісний зв'язок 3 фольклорною обрядовістю, корені якої сягають у глибину тисячоліть, а через них філософська зосередженість на вічних проблемах буття, на які немає і не може бути однозначної відповіді» (2001: 12).

Визначеними вище цими ментальними рисами дослідниця пояснює дві важливі ознаки української музичної культури. По-перше «обережну» трансформацію українською композиторською школою авангардних концепцій 
і засобів, викристалізуваних в експериментаторських пошуках західноєвропейських мистців. По-друге - домінування у творіннях композиторської, як i літературно-поетичної, театральноїтаобразотворчої,шкіл «акласичних» стилів, насамперед, бароко і романтизму, питомими рисами яких є чуттєвість й ірраціональність, що мають у витоках багатотисячолітні поняття і символи колективного світогляду та $є$ «зерном» національного мистецтва (Кияновська, 2001: 11-12), - природньо, саме ці стилі найбільш глибоко резонують 3 національною ментальністю.

До наведеного дискурсу варто додати й ідею О. Катрич, висловлену у контексті концепції музично-виконавського стилетворення. Уявляючи ментальність як субстанцію, яка, «експонуючи найзагальніший рівень прояву національного... існує в етнічно визначеному соціумі, де кожен представник соціуму $є$ iï носієм» (Катрич, 1996: 32), дослідниця стверджує й про домінуючий тип стилетворення для музично-виконавської школи, який за своєю суттю також $є$ акласичним, - це характерний для національно-ментального вираження діонісійський архетип.

Описані вище національно-ментальні риси, на нашу думку, зумовлені практикою глибинної саморефлексії, що є предвічною українською традицією, вершинним виявом якої став сковородинський «подвиг самопізнання». Цим же пояснюємо і помічену Л. Кияновською вкрай рідку появу української композиторської школи в авангарді мистецьких пошуків, непритаманність для іiі вираження духу експериментаторства, радикалізму у зламі існуючих технологій, прагнення шокувати публіку тощо. Це викликає чисельні паралелі в інших сферах української культури та, у цілому, українського мислення, виражені символікою головних архетипів колективного безсвідомого - як ключових, пов'язаних із софійністю і кордоцентризмом, так і багатьох інших.

У цілому, естетика засадничого етапу еволюції українського і професійного, і народного мистецтва - доби бароко, і особливо близький українцям «бароковий дуалізм мислення» дозволили «природно поєднати глибоку релігійність, а часом і ірраціональну містичність погляду на світ з іскристою дотепністю чуттєвої насолоди, буфонно-гротесковими фантаста- горіями, химерними переплетеннями вигадки i дійсності, протилежних полюсів почування й буття» (Кияновська, 2007: 362). Цей дуалізм і презентує у музичній культурі сутність національної ментальності.

У продовження роздумів про домінування в українській культурі акласичної стилістики приходимо до висновку, що після довершеного козацького бароко, у період, коли в західноєвропейській музиці панував класицизм, оснований на «ratio» (ментальному відокремленні Розуму і Серця), в українській розвинувся сентименталізм з зерном «еmotio». Класики української музики М. Березовський, Д. Бортнянський, А. Ведель по-різному втілювали пізньобарокові-ранньокласичні тенденції, не творячи «класичного класицизму» австро-німецького зразка з ідеєю вищого розуму і космічно-числового порядку. Розум української ментальності $\epsilon$ за суттю «сердечним розумом», витвореним iз поєднання архетипів Софії і Серця, а вищий порядок трактується як музикальність світу, числова гармонія якого сприймається крізь призму власного серця. Більше того, незаперечною вершиною національної класики стала творчість Івана Котляревського, його блискучі гумор і гротеск, які репрезентували «світ навиворіт» - українську сміхову культуру, в якій також вбачаємо ірраціональний первінь. Із цих же причин, на нашу думку, в українській музиці не зреалізувалися у вигляді цілісних течій раціоналізовані математично-орієнтовані пошуки авангарду XX ст., виявлені в окремих індивідуальних випадках.

Згадані архетипи Серця і Софії є знаками ментального кордоцентризму, котрий, проявившись у музиці, витворив кордоцентризм музичний, який трактується як «вираження основних засад філософії серця специфічними засобами композиторського письма, що включає певні естетико-стильові пріоритети, окреслений вибір жанрових та драматургічних моделей, ієрархію складових музично-виразової системи» (Завісько, 2013: 8). Авторка стверджує, що кордоцентризм, що став домінуючою рисою національної музичної ментальності, має витоки у XVI-XVII ст. в ісихазмі, провідна ідея сердечного пізнання Бога відображена у кантах і псальмах Д. Туптала, Ф. Прокоповича, Т. Щербацького, лірико-рефлексивній настроєвості партесних концертів, отримав 
найяскравіше вираження у бароковому і романтичному стильових виявах, між тим у «золоту добу» в сентименталізмі А. Веделя, у провідній сфері національної культури - вокальній, специфічному національному камерному мисленні, в елегійності як трансформації кордоцентричних ідей. Вказуючи на провідну роль сердечних почуттів, волі та відчуттів у пізнанні Божественної істини ще у трактатах давньоруських мислителів Іларіона Київського, Володимира Мономаха, Кирила Туровського, Данила Заточника, які розуміли існування людини як постійну боротьбу, що зосереджується у Серці - боротьбу між світлом і пітьмою, між вищою благодаттю та диявольською прірвою, у тому, що Серце «сполучає розум, почуття й волю людини, а водночас найбільше резонує на гармонію музичних звучань» (Завісько, 2013: 8), - авторка вбачає й виключний український пієтет до духовної творчості, і композиторської, і виконавської.

На нашу думку, із вказаних ментальних причин провідними жанрами української музичної культури є співочі - вокальні і хорові. Українська вокальна школа, на думку В. Антонюк, не орієнтована, як західноєвропейські та американські етнокультурні школи, на пошуки дослідницьких матеріалів поза сферою власного етнічного середовища. Вона $\epsilon$ національно-орієнтованою, тому їі сутність як «етномистецтвознавчого модусу в системі сучасної світової культури» (Антонюк, 2001: 6) визначається сутністю національної ментальності. На цих же підставах дослідник I. Присталов називає українську вокальну школу «школою ліричного співу» і розкриває поняття ліризму у контексті української художньої ментальності. «Ліризм трактується як жанрова основа i, внаслідок цього, як стильова особливість оперного мистецтва в цілому, національної української опери зокрема і стилю вокальної інтерпретації оперних партій» (Присталов, 2008: 2). У порівнянні із лірикою у західноєвропейському оперному співі, «лірикоцентричність національного художнього менталітету», стверджує I. Присталов (2008: 7), має суттєву специфіку, зокрема, особливу естетизуючу семантику ліричного тенора (піднесене і статично-урочисте виконання 3 високо розвиненою технікою мелізматичного співу та виразним інтонуванням у високому регістрі), зв'язок
3 манерою виконання народних пісень і міських романсів, освоєння італійської манери співу, відображення образів ліричної природи як найбільш органічно традиційних для національної культури, спорідненість із традицією церковного співу, модус якої сформувався на основі візантійської традиції у добу середньовіччя, над-індивідуальний та етично піднесений, сповідальний пафос, витоки якого - у традиції культового співу. Як вказала щодо цього О. Бенч-Шокало, «прийнявши канон візантійського обряду, українці трансформували його відповідно до власної співочої традиції: канонічні тексти осмислювалися суто індивідуально» (2002: 11), що зумовило трактування Літургії з позицій безпосереднього індивідуального осягнення людиною Бога через власне серце, - нагадаємо, ця ідея сповна зреалізувалася у філософії українського кордоцентризму Г. Сковороди та П. Юркевича, християнського персоналізму М. Гоголя і М. Бердясва та ін.

Зазначимо, що вказані питомі ознаки етосу української духовної музики, зумовленого домінуючим кордо- первнем, зумовлюють ще одну його рису - настроєву двоїстість, тобто амфотерність, яка полягає у тому, що радість та інші оптимістичні емоції виражаються засобами мінорного ладу. Мова йде про перехрещення різнозабарвлених емоцій, як, наприклад, радість і смуток, тобто їхню амфотерній музиці викликає хіазму. Гіпотезу про амфотерну музику та музичну хіазму як модальну рису слов' янської душі відстоюють психологимузикотерапевти I. Мірошник та С. Гаврилін. Не заглиблюючись у даному сферу у рамках музикознавчого дослідження, лише констатуємо, явище хіазми вчені обгрунтовують домінантністю правопівкульного емоційно-образного сприйняття світу і художнього мислення, який характеризується цілісністю та симультанністю, і за певних обставин може доповнюватися лівопівкульним мисленням, що привносить у процес мислення раціонально-логічні і сукцесивні ознаки. Відтак, вважають дослідники, східнослов'янський етос має за головну «смислотворчу» функцію у світовій культурі, західноєвропейський - «цілевизначаючу» (Мирошник и Гаврилин, 1999).

Науковий дискурс щодо проблем національної ментальності і музики має і семіологічний аспект, який в українській науковій традиції 
бере витоки у дослідженнях О. Потебні (1892), котрий обгрунтував поняття «мова мистецтва» та «мова культури» та, спираючись на досягнення А. Гумбольдта, продекларував тезу про знаково-символьну природу мистецтва (3-поміж іншого, вчений приводить приклади «крокового колеса» як символу Сонця та ін.). Окрім того, у доробку вченого знаходимо надзвичайно цінну як для того часу, так і для нашого дослідження ідею про зумовленість творчості мисленням, крізь яке навколишній світ відображається у душі мистця, тобто, про ментальні основи мистецтва (подаємо мовою оригіналу): «Искусство ... есть не непосредственное отраженіе природы въ душъ, а извъстное видоизмъненіе этого отраженія. Между произведеніемъ искусства и природою стоить мысль человька только подъ этимъ условіемъ искусство можетъ быть творчествомъ» (Потебня, 1892: 189-190).

У сучасному музикознавстві семіологічний погляд актуалізовано у дослідженнях О. Козаренка, який розглядає музику як «специфічну семіотичну систему» (2001: 2) та пропонує перехід від «історії стилів», проблемного чи традиційно-наративного історієписання до «історії ментальностей» (2001: 13-14). В історії української музики дослідник вирізняє «передстиль» - до першої половини XIX ст. включно, «стиль» - творчість М. Лисенка та «метастиль» - спадщина, що з'явилася від від 60-х pp. ХХ ст. Стверджуючи про стиль як мовну єдність, про багатомовність сучасної музичної творчості, вчений у сучасному музичному континуумі, у постмодерному «накладанні» декількох стильових парадигм (подібному до того, що було в українській музиці XVII-XVIII ст., у бароково-сецесійно-ранньокласичному «накладанні»), вирізняє «наџіональний мово-стиль», утворений з інтегральних складових, якими $\epsilon$ авторські музичні «словники» (Козаренко, 2001: 28, 218-254). Зазначимо, що, безумовно, національний стиль не $є$ буквальною сукупністю множинних авторських стилів, а сутнісно більш цілісним явищем, яке живе за законами сучасності і народжує вказані дослідником індивідуальні стилі.

Наступний аспект експлікації феномену ментальності у музикознавстві, якого торкаємося у представленій статті, пов'язаний із колективним безсвідомим, архетипи якого $є$ «провідниками» цілісного відображення національ- ного мислення у музиці. Перехід архетипів від «культурного позасвідомого» до реального висвітлення у художній творчості, до реалізації у музичному творі здійснюється крізь призму мислення композитора-виконавця-слухача, у свідомості яких постає музичний твір. Схема цього переходу описана дослідниками, які висунули термін «культурне позасвідоме», А. Пелипенком та I. Яковенком (1998).

Згаданий ракурс проблеми опрацьований у дослідженні М. Северинової, в якому здійснюється проєкція архетипів культури на творчість сучасних українських композиторів (Архетипи..., 2013). У цілому, авторка приходить до висновку, що відображений в музиці першообраз ніби перекладається композитором зрозумілою для сучасників мовою, а також наполягає на колективно позасвідомій сутності архетипів, що постають у композиторській творчості як першообрази, котрі формувалися і функціонували у міфології і традиції.

Дослідниця вирізняе три рівні «основи художнього творення» (М. Гайдеггер) або художнього мислення: перший рівень - абстрактний, що знаходиться у царині колективного позасвідомого, відтак із всесвітнього поля існуючих культурних архетипів продукує одвічні ідеї, що не залежать від історичного часу, національності, соціального статусу, психологічного або творчого станів композитора, цей рівень «найближчий до первинного пласта ментальності, оскільки він несе в собі першообрази, первинні імпульси та реакції, що викликають проекцію на свідомість (точніше, позасвідомість)» (Северинова, Теорія..., 2013: 182); другий рівень - це «позасвідомий культурний код», що переносить національні культурні архетипи у творчості композитора; він складається із тих смислів та образів, які автор, як представник культурної традиції, свідомо чи несвідомо закладає у свою творчість (Северинова, Теорія..., 2013: 182); і нарешті, третій рівень - «свідомо закладений композитором культурний код, що свідчить про особистісні композиторські ідеї та створення особистісних архетипів, а, може, й кенотипів» (Северинова, Теорія..., 2013: 182-183).

Висновки і перспективи подальших досліджень. Сучасне українське музикознавство, що у ситуації становлення української державності було покликане докладати зусиль до національного гуманітарного розвитку, напрацювало 
певні здобутки в експлікації феномену ментальності, що стало предметом даного дослідження. У цілому, в них продовжено пошуки С. Людкевича (1999: 52) про вільну взаємодію життя і мистецтва як сутнісне ядро формування ментальності певної культури. Найбільш вагомими, на нашу думку, є ідеї І. Ляшенка (1973; 1991) про диференціацією національного та універсального способів мислення як ментальних виявів, обгрунтування Н. Горюхіною (1985) та Н. Герасимовою-Персидською (1999) проявів національної ідентичності в музиці, ідеї Л. Кияновської (2001) про «обережну» трансформацію українською композиторською школою авангардних концепцій та домінування акласичних стилів як результат кордоцентризму національної ментальності, О. Катрич (1996) - про діонісійський архетип як домінуючий в українському музично-виконавському стилетворенні, диференціація М. Севериновою (Теорія..., 2013) рівнів художнього мислення у відповідності до положень теорії колективного безсвідомого К. Г. Юнга та ін.

Докладаючи зусиль для опрацювання вказаного аспекту проблеми, пропонуємо ідею диференціації архетипів колективного безсвідомого, які є основою художньої творчості, на два типи. Перший - інваріантні архетипи, якими вважаємо ті основоположні архетипи, які є символами певних явищ і функціонують у колективному безсвідомому людства. Другий тип - варіантні архетипи, які є «символами символів» і проявляються у мистецтві крізь призму ментальності його творців. Наприклад, інваріантний архетип Аніма може проявляться у музиці множинністю фемінних образів, пов'язаних з архетипами Дівчини, Матері, Землі та ін., інваріантний архетип Анімус - маскулинними образами, що символізують Воїна, Мудрого старця та ін., що має безліч прикладів у світовому та українському музичному мистецтві. «Знаковими» прикладами відображення вказаних архетипів в українській музиці ряд вокальних, хорових і сценічних творів, як, наприклад, кантати «Весна» М. Скорика, «Червона калина» Л. Дичко, «Україна. Хресна дорога» В.Камінського та багато інших, аналіз яких розкриває додаткові можливості до самоусвідомлення та вивчення найбільш яскравих рис національної психології.

Перспективи подальших досліджень вбачаємо в аналізі природи і механізмів відображення ментальності в музиці, а також у вивченні окремих архетипів, характерні риси і специфіка втілення яких у музиці є свідченням тих чи інших ментальних ознак.

\section{ЛIТЕРАТУРА:}

1. Антонюк В. Г. Українська вокальна школа: етнокультурологічний аспект [2 вид., перероб і доп.]. Київ : БМКП центр «Українська ідея», 2001. 142 с.

2. Безбородько О. А. Національно-вербальний фактор музичної творчості : автореф. дис. ... канд. мистецтвознав. : 17.00.03. Київ, 2010.16 с.

3. Бенч-Шокало О. Г. Український хоровий спів. Актуалізація звичаєвої традиції : Навч. посіб. для студ. вищ. навч. закл. Київ : Ред. журн. «Український Світ», 2002. 440 с.

4. Герасимова-Персидская Н. К проблеме национальной идентичности в музыке. Проблемы нащиональных музыкальных культур на рубеже третьего тысячелетия : Материаль международной научной конференции. Минск : БелИПК, 1999. С. 35-42.

5. Горюхина Н. Методика анализа национального стиля. Горюхина Н. А. Очерки по вопросам музыкального стиля и формыл. Киев : Музична Україна, 1985. С. 81-99.

6. Завісько Н. 3. Прояви кордоцентризму в українській музичній культурі : автореф. дис. ... канд. мистецтвознав. : 17.00.03. Львів, 2013. 16 с.

7. Казимирів Х. Т. Міфологема землі в українській професійній музиці: історико-культурологічний аспект : автореф. дис. ... канд. мистецтвознав. : 26.00.01. Київ, 2018. 19 с.

8. Катрич О. Національна специфіка української музики. Український світ. 1996. №4. С. 32.

9. Кияновська Л. Галицька музична культура XIX-XX століття : навч. посіб. для вищ. навч. закл. Чернівці : Книги-XXI, 2007. 424 с.

10. Кияновська Л. Український музичний романтизм в європейському контексті. IV Міжнародний конгрес україністів : Доповіді та повідомлення. Мистеитвознавство. Одеса - Київ : Вид-во Асоціації етнологів, 2001. C. $11-12$.

11. Козаренко О. В. Українська національна музична мова: генеза та сучасні тенденції розвитку : автореф. дис. ... д-ра мистецтвознав. : 17.00.03. Київ, 2001. 35 с. 
12. Корній Л. Проблема національної ідентичності української музичної культури (на прикладі духовної музики). Часопис Національної музичної академії України ім. П. І. Чайковського. 2008. №1 С. 97-103.

13. Кулик В. Любов Кияновська про музикознавство сучасне і майбутнє [розмову вела Любов Назар]. Музика : украӥнський інтернет-журнал. 16 червня 2019 року. URL : http://mus.art.co.ua/liubov-kyianovs-ka-promuzykoznavstvo-suchasne-i-maybutnie/ (25.06.2021).

14. Людкевич С. Націоналізм у музиці. С. Людкевич. Дослідження, статті, рецензії, виступи / упор. 3. Штундер. Львів : Вид-во М. Коць, 1999. Том І. С. 35-52.

15. Ляшенко І. Національне та інтернаціональне в музиці. Київ : Наукова думка, 1991. 269 с.

16. Ляшенко І. Національні традиції в музиці як історичний процес. Київ : Музична Україна, 1973. 328 с.

17. Мирошник И. М., Гаврилин Е. В. Основы личностно-ориентированной компьютеризованной психотерапии : монография. Харьков : Рубикон, 1999. 240 с.

18. Новакович М. Галицька музика габсбурзької доби (1772-1918) в контексті явища національної ідентичності : автореф. дис. ... д-ра мистецтвознав. : 17.00.03. Одеса, 2020. 33 с.

19. Пелипенко А. А., Яковенко И. Г. Культура как система. Москва : Языки русской культуры, 1998. 376 с. (Язык. Семиотика. Культура).

20. Плечелюк Г. Інтерпретація форм архетипу Переродження в українському музичному мистецтві (проекція теорії архетипів Карла Густава Юнга). Наукові записки Тернопільського національного педагогічного університету ім. В. Гнатюка. Сер. Мистецтвознавство. 2016. № 2. С. 78-89. URL: http://nbuv.gov.ua/UJRN/NZTNPUm_2016_2_12 (22.06.2021).

21. Потебня А. А. Мысль и язык [2-е издание]. Харьковъ : Типографія Адольфа Дарре, Рыбная улица, № 28, 1892. 228 c. URL : https://archive.org/details/libgen_00702348/page/n91/mode/2up?view=theater (20.06.2021).

22. Присталов І. К. Ліризм як жанрова основа українського оперного співу : автореф. дис. ... канд. мистецтвознав. : 17.00.03. Одеса, 2008. 16 с.

23. Самойленко А. Психологические предпосылки культурологического анализа: размышление о методе. Київське музикознавство. Культурологія та мистецтвознавство. 2004. Вип. 15. С. 3-15.

24. Северинова М. Ю. Архетипи в культурі у проекції на творчість сучасних українських композиторів : автореф. дис. ... д-ра мистецтвознав. : 26.00.01. Київ, 2013. 36 с.

25. Северинова М. Ю. Теорія К. Г. Юнга про архетипи та ії вплив на художню (музичну) культуру. Культура Украӥни. 2013. Вип. 40. С. 176-184.URL: https://ic.ac.kharkov.ua/nauk_rob/nauk_vid/rio_old_2017/ku/kultura40/24.pdf(25.06.2021).

26. Ярко М. Парадигма етнонаціональної ідентичності української музичної творчості як пріоритетна дослідницька проблема сучасного вітчизняного музикознавства. Наукові записки Тернопільського національного педагогічного університету імені Володимира Гнатюка. Серія : Мистещтвознавство. 2013. № 2. С. 40-48.

\section{REFERENCES:}

1. Antoniuk, V. H. (2001). Ukrainska vokalna shkola: etnokulturolohichnyi aspekt [Ukrainian vocal school: ethnocultural aspect]. Kyiv: Ukrainska ideia [in Ukrainian].

2. Bezborodko, O. A. (2010). Natsionalno-verbalnyi faktor muzychnoi tvorchosti [National-verbal factor of music creativity]. Thesis abstract for Cand. Sc. (Arts), 17.00.03. Kyiv [in Ukrainian].

3. Bench-Shokalo, O. H. (2002). Ukrainskyi khorovyi spiv. Aktualizatsiia zvychaievoi tradytsii [Ukrainian choral singing. Actualization of customary tradition]. Kyiv: Ukrainskyi Svit [in Ukrainian].

4. Gerasimova-Persidskaya, N. (1999). K probleme nacional'noj identichnosti v muzyke [To the problem of national identity in music]. Problemy nacional'nyh muzykal'nyh kul'tur na rubezhe tret'ego tysyacheletiya: Materialy mezhdunarodnoj nauchnoj konferencii. Minsk: BelIPK, 35-42 [in Russian].

5. Goryuhina, N. (1985). Metodika analiza nacional'nogo stilya [National style analysis method]. Goryuhina, N. A. Ocherki po voprosam muzykal'nogo stilya i formy. Kiev: Muzychna Ukraina, 81-99. [in Russian].

6. Zavisko, N. Z. (2013). Proiavy kordotsentryzmu v ukrainskii muzychnii kulturi [Cordocentrism manifestations in Ukrainian musical culture]. Thesis abstract for Cand. Sc. (Arts), 17.00.03. Lviv [in Ukrainian].

7. Kazymyriv Kh. T. Mifolohema zemli v ukrainskii profesiinii muzytsi: istoryko-kulturolohichnyi aspekt [Earth mythologism in Ukrainian professional music: historical and cultural aspect]. Thesis abstract for Cand. Sc. (Arts), 26.00.01. Kyiv [in Ukrainian].

8. Katrych, O. (1996). Natsionalna spetsyfika ukrainskoi muzyky [National specifics of Ukrainian music]. Ukrainskyi svit. 4, 32 [in Ukrainian].

9. Kyianovska, L. (2007). Halytska muzychna kultura XIX-XX stolittia [Galician musical culture of the 19-20 th centuries]. Chernivtsi: Knyhy-XXI [in Ukrainian].

10. Kyianovska, L. (2001). Ukrainskyi muzychnyi romantyzm v yevropeiskomu konteksti [Ukrainian musical romanticism in the European context]. IV Mizhnarodnyi konhres ukrainistiv : Dopovidi ta povidomlennia. Mystetstvoznavstvo. Odesa - Kyiv : Vyd-vo Asotsiatsii etnolohiv, 11-12 [in Ukrainian]. 
11. Kozarenko, O. V. (2001). Ukrainska natsionalna muzychna mova: heneza ta suchasni tendentsii rozvytku [Ukrainian national musical language: genesis and current trends]. Thesis abstract for Doct. Sc. (Arts), 17.00.03. Kyiv [in Ukrainian].

12. Kornii, L. (2008). Problema natsionalnoi identychnosti ukrainskoi muzychnoi kultury (na prykladi dukhovnoi muzyky) [The problem of national identity of Ukrainian musical culture (on the example of sacred music)]. Chasopys Natsionalnoi muzychnoi akademii Ukrainy im. P. I. Chaikovskoho. 1, 97-103 [in Ukrainian].

13. Kulyk, V. (2019). Liubov Kyianovska pro muzykoznavstvo suchasne i maibutnie [Lyubov Kiyanovska about modern and future musicology]. Muzyka: ukrainskyi internet-zhurnal. 16 chervnia 2019 roku. URL: http://mus.art.co.ua/ liubov-kyianovs-ka-pro-muzykoznavstvo-suchasne-i-maybutnie/ (25.06.2021) [in Ukrainian].

14. Liudkevych, S. (1999). Natsionalizm u muzytsi [Nationalism in music]. S. Liudkevych. Doslidzhennia, statti, retsenzii, vystupy. Lviv: Vyd-vo M. Kots. Tom I, 35-52 [in Ukrainian].

15. Liashenko, I. (1991). Natsionalne ta internatsionalne $v$ muzytsi [National and international in music]. Kyiv: Naukova dumka [in Ukrainian].

16. Liashenko, I. (1973). Natsionalni tradytsii v muzytsi yak istorychnyi protses (National traditions in music as a historical process). Kyiv: Muzychna Ukraina [in Ukrainian].

17. Miroshnik, I. M., Gavrilin, E. V. (1999). Osnovy lichnostno-orientirovannoj komp'yuterizovannoj psihoterapii [Fundamentals of Personality-Oriented Computerized Psychotherapy]. Har'kov: Rubikon [in Russian].

18. Novakovych, M. (2020). Halytska muzyka habsburzkoi doby (1772-1918) v konteksti yavyshcha natsionalnoi identychnosti [Galician music of the Habsburg era (1772-1918) in the context of the phenomenon of national identity]. Thesis abstract for Doct. Sc. (Arts), 17.00.03. Odesa [in Ukrainian].

19. Pelipenko, A. A., Yakovenko, I. G. (1998). Kul'tura kak sistema [Culture as a system]. Moskva: Yazyki russkoj kul'tury [in Russian].

20. Plecheliuk H. Interpretatsiia form arkhetypu Pererodzhennia v ukrainskomu muzychnomu mystetstvi (proektsiia teorii arkhetypiv Karla Hustava Yunha) [Interpretation of the Rebirth archetype forms in the Ukrainian musical art (the projection by Karl Gustav Jung's archetypes theory)]. Naukovi zapysky Ternopilskoho natsionalnoho pedahohichnoho universytetu im. V. Hnatiuka. Mystetstvoznavstvo. 2016. 2, 78-89. URL : http://nbuv.gov.ua/UJRN/ NZTNPUm_2016_2_12 (22.06.2021) [in Ukrainian].

21. Potebnya, A. A. (1892). Mysl' i yazyk [Thought and language]. Har'kov": Tipografiya Adol'fa Darre, Rybnaya ulica, № 28. URL: https://archive.org/details/libgen_00702348/page/n91/mode/2up?view=theater (20.06.2021) [in Russian].

22. Prystalov, I. K. (2008). Liryzm yak zhanrova osnova ukrainskoho opernoho spivu [Lyricism as a genre basis of Ukrainian opera singing]. Thesis abstract for Cand. Sc. (Arts), 17.00.03. Odesa [in Ukrainian].

23. Samojlenko, A. (2004). Psihologicheskie predposylki kul'turologicheskogo analiza: razmyshlenie o metode [Psychological preconditions for cultural analysis: reflection on the method]. Kï̈vs'ke muzikoznavstvo. Kul'turologiya ta mistectvoznavstvo. 15, 3-15 [in Russian].

24. Severynova, M. Yu. (2013). Arkhetypy v kulturi u proektsii na tvorchist suchasnykh ukrainskykh kompozytoriv [Archetypes in culture in projection on the Ukrainian composers contemporary works]. Thesis abstract for Doct. Sc. (Arts), 26.00.01. Kyiv [in Ukrainian].

25. Severynova, M. Yu (2013). Teoriia K. H. Yunha pro arkhetypy ta yii vplyv na khudozhniu (muzychnu) kulturu [Jung on archetypes and its influence on artistic (musical) culture]. Kultura Ukrainy. 40, 176-184. URL: https://ic.ac. kharkov.ua/nauk_rob/nauk_vid/rio_old_2017/ku/kultura40/24.pdf (25.06.2021) [in Ukrainian].

26. Yarko, M. (2013). Paradyhma etnonatsionalnoi identychnosti ukrainskoi muzychnoi tvorchosti yak priorytetna doslidnytska problema suchasnoho vitchyznianoho muzykoznavstva [The paradigm of ethno-national identity of Ukrainian musical creativity as a priority research problem of modern domestic musicology]. Naukovi zapysky Ternopilskoho natsionalnoho pedahohichnoho universytetu imeni Volodymyra Hnatiuka. Mystetstvoznavstvo. 2, 40-48 [in Ukrainian]. 